\title{
QUEERISATION OF MEDIUM. TO THE QUEER PLASTICITY OF SIGN STRUCTURE
}

\author{
Ilya D. Deikun ${ }^{a}$ \\ ${ }^{a}$ Maxim Gorky Literature Institute. 25 Tverskoy Boulevard, Moscow, Russia 1259932. \\ Email: iliariy[at]mail.ru
}

\begin{abstract}
This article focuses on the study of emancipatory strategies and reveals contradictions between the rhetorical strategy in the Cyborg Manifesto and its pragmatics, on the one hand, and the discrepancy between the content and the social reflection of the concept of "multiple gender" developed by Judith Butler in Gender trouble, on the other. The author started to unfold this problematic in the paper Fleeing Queer (Vita Cogitans, 2019).

The author argues that the main reason for these contradictions is the inherent neglect of sign-medium specificity by structuralists. Following the criticism initiated by Regis Debray who proposes a new vision of sing focused on its materiality, the author outlines a way to the range of genres which seems to be more adequate to the rates of Cyborg Manifesto and proposes to consider practices which save the room for multiplicity and indeterminacy in the sense of Bergson, Matière et Mémoire, on the level of sign-medium. From this perspective the sign-medium continuum makes us seek for what we could indicate as "queerisation of medium". We show the corresponding possibilities on the example of the alphabet and writing invented by a Moscow artist Anya Belousova.
\end{abstract}

\section{Keywords}

sign; medium; queer; gender multiples; Debray; Butler; Haraway, Foster, Cyborg Manifesto; total design; artistic alphabet

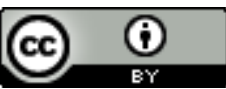

This work is licensed under a Creative Commons Attribution 4.0 International License. 


\title{
КВИРИЗАЦИЯ МЕДИА. К КВИР-ПЛАСТИЧНОСТИ ЗНАКОВОЙ СТРУКТУРЫ
}

\author{
Дейкун Илья Дмитриевича \\ а ФГБОУ «Литературный институт имени А.М. Горького». 125993, Российская \\ Федерация, Москва, ул. Тверской бульвар, д. 25. Email: iliariy[at]mail.ru
}

\section{Аннотация}

Данная статья посвящена исследованию эмансипаторных стратегий и раскрывает противоречия между риторической стратегией «Манифеста Киборгов» и его прагматикой, с одной стороны, и несоответствием содержания и социального отражения концепции «множественного гендера», разработанной Джудит Батлер в книге «Gender trouble», с другой.

Автор начал разрабатывать эту проблему в статье «Квир убегающий» (Vita Cogitans, 2019). Автор утверждает, что основной причиной этих противоречий является присущее структуралистам пренебрежение медиальной стороной знака. Вслед за критикой, инициированной Режи Дебре, который предлагает новое видение знака, ориентированное на его материальность, автор намечает путь к диапазону жанров, который кажется более адекватным ставкам «Манифеста Киборгов», и предлагает рассмотреть практики, которые сохраняют место для множественности и неопределенности в смысле, используемом Бергсоном в «Matière et Mémoire», на уровне медиума. С этой точки зрения континуум знак-медиум заставляет нас искать то, что мы могли бы обозначить как «квиризацию медиума», возможность которой автор демонстрирует на примере алфавита и соответствующей письменности, изобретенных московской художницей Аней Белоусовой.

\section{Ключевые слова}

знак; медиум; квир; множественный гендер; Дебре; Батлер; Харауэй; Манифест Киборгов; тотальный дизайн; художественный алфавит

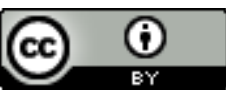

Это произведение доступно по лицензии Creative Commons «Attribution» («Атрибуция») 4.0 Всемирная. 


\section{INTRODUCTION}

In the previous article, Fleeing queer (Vita Cogitans, 2010) which directly precedes this study, I contrasted the utopian project of Donna Haraway's Cyborg Manifesto, where she tries to "think utopia", with the largely pessimistic analysis of modernity conducted by Hal Foster in his article Design and crime. While the former tends to consider, in a quite futurological way, the options of the future emancipation by means of fusion of fundamental opposites, like "female" and "male", "machine" and "biological", namely, by "holding incompatible things together" (Haraway \& Wolfe, 2016, p. 5), the latter starts from the historical point and sees in this fusion provided by performative force of the omnipresent technology something between Gesamtkunstwerk and rebranded "society of spectacle" (Debord, 1992). This raises the question: what turns the emancipatory enterprises into the opposite? Although we are aware that the theoretical claim of Manifesto project is, following Jameson's phrase, that of mapping utopia (Jameson,1992), its explicit utopian character and rather a realistic focus redirected my attention towards the analysis of the pragmatics of rhetorical strategies involved in Manifesto, which seem to be constrained by the chosen literary genre. Also, it urges us to proceed by switching the core theoretical approaches from the probing-future fictions to performative language acts tending to establish conceptual frame for utopia in the present through the theoretical prise de position, which consists, in contrast to Haraway's ideas, in changing the modality of utopia. From now on, the hidden potentiality will be revealed in the structure of common sense. This is the project of Judith Butler, who seeks for rethinking gender binarity that would open the way to multiplicity (Butler, 1990). This promising approach, though, has been unable to withstand the test of reality. Such a social phenomenon puts in the limelight the fact that "queer", the later term for gender multiplicity, goes no further than a theoretical abstraction misunderstood by social agents (Johnson, 2001); therefore it does not respond to the principles of performative enunciation (Austin, 1962). The first part of our paper is dedicated to the two discrepancies between, on the one hand, fictional modality, rhetorical arrangement and political bid of 
Manifesto, and, on the other, performative structure and performativity in Gender Trouble. In the second part we suggest the different approach to the emancipatory practices and propose a hypothesis: if "queer", by a handful of its characteristics reflected in its political manifestations (Epstein, 1987; Johnson, 2001; Callis, 2009) and conceptual history (Whilkins, 2004) is rather a sign of an "off kitler" (Johnson, 2001, p.1) from etymological perspective, and, in its postmodern heritage, of negation not only of fixed identity, but of its categorization, could we suppose political identity to be a forced and false referent? Could we, while considering the "queer" as a sign of the referential inability, and so to speak, its failure as a sing in semiotic sense (Atkin, 2007; Atkin, 2013; Saussure, 1966), rethink sign structure and underline the importance of its material facet, its medium? The criticism of structuralism led by Regis Debray (Debray, 1996) provides tools for effective indicating what could be "queer" from this perspective. Indeed, this reformulation implies the parallel question what the queer as medium is, and stimulates the study of the class of phenomena, which could respond to the principles of queer as political identity but reducing it to the pure description of sign qualities. First and foremost, this reduction has to open the way for acknowledging its inherent multiplicity. As an example, we offer the original alphabet and writing invented by Moscow artist Anya Belousova, which with its specific rules of writing and ever-changing deciphering stands out from usual draft practices seeming to come close to our interpretation of "queer", and which specificity is highlighted in the seminal article by Almouth Grésillon (Grésillon, 1988).

\section{FROM GENRE DEFICIT TO THE MEDIUM AS GENRE}

At the beginning of the Manifesto, Haraway claims that "cyborg" is a "rhetorical strategy", "...a political method", "world-changing fiction", and finally, "fiction mapping our social and bodily reality" (Haraway \& Wolfe, 2016, pp. 5-6). A rhetorical strategy that appeals to the "possible" becomes a performative statement precisely because of the substitution of its meaning, which is characteristic of irony. Cyborg is subversion, an ironic subversion of political meaning. This projective identity is assembled beyond the traditional oppositions; it marks the 
transition from the Organics of domination to the Informatics of Domination, in other terms, from the clinically adjusted "natural" (Drescher, 2007) to the technically constructed identity. For this the leading narrative strategies are found in postmodern literature and science fiction, offering the most appropriate strategies for considering hybridity, combining oppositions and projected self. The choice of genre becomes a matter of paramount importance when in chapter Cyborgs: a Myth of Political Identity, Haraway tells that feminist science-fictions is "material and cultural grids mapping this potential" (Haraway \& Wolfe, 2016, p. 54).

Here it is appropriate to recall Frederick Jameson indicating the point "at which the feminist project and the Marxist, socialist project converge and are faced with the same dilemma: how to imagine a Utopia" (Jameson, 1990). Crucified on the grid of discursive patterns Haraway's attempt to depict Utopian identity is sentenced by its own discursive choice to reveal its own inability "of recoding communication and intelligence to subvert command and control" (Haraway \& Wolfe, 2016, p. 56).

The fact is that science fiction itself forces rather a conservative mode of deploying narration on several levels at once. T. Todorov defines them as "utterance", "act of uttering", and "syntax" (Todorov, 1975, p. 76). It is noteworthy that we can find in the rhetorical rate of Manifesto something of a fantastic discourse, namely, the acquisition of a proper meaning by a figurative expression. Political irony becomes identity. The instance of the narrator, the second level of structure after Todorov, is not as important as the level of syntax. The intrigue of the genre which constitutes a fantastic narrative refers directly to the previous state of things, to the Organics of Domination, and in particular, to the bourgeois novel. This short circuit of the genre scheme is not overcome by irony, since the reverse meaning implied by it appears to be beyond the boundaries of the utterance, that is, in the event.

In Gender trouble Judith Butler refers to the reverse side of the statement. She reverses the conventional definition of a body as a "mere medium for which a set of cultural meanings are only externally related". She adds that "the body it itself a construction" (Butler, 1990, p. 8). This refers the problem of freedom of "body" to the discourse that sets limits to analysis, in 
other words, it encourages us to reject the system of sign structure, to move to a new level of signification, where identity becomes multiplicity "whose totality is permanently deferred, never fully what it is at any given juncture in time" (p. 8). In changing modality, Butler says, "it will be an open assemblage that permits of multiple convergences and divergences without obedience to a normative telos of definitional closure" (p.16). The embodiment of this uninhibited discursive plurality is "queer" that avoids in its meaning the regulatory practices of discourse and discovers the possibility for "feminine writing"18 (Butler, 1990, p.26). The only problem is that the reconfiguration of the discursive field occurs without becoming performative. According to Austin's description of performative sentence, "to utter the sentence (in, of course, the appropriate circumstances) is not to describe my doing of what I should be said in so uttering to be doing or to state that I am doing it: it is to do it" (Austin. 1962, p. 6). Brackets are very important here. One of the preliminary conclusions about the reasons of the apparent failure to find the "cyborg" identity in classic narratives, on the side of Haraway, and the lack of real social referent of the created "signifier", on the side of Butler, is that there is discrepancy between the speech act and the necessary conditions for its utterance.

My previous thesis (Fleeing Queer, Vita Cogitans, 2019) on the profitable coincidence of performative enunciation essential for programming language (Arns, 2005) and video game environment has not been confirmed. The marginal cultures of queer-indie games, which correspond to the problems of discursive subversion, did not, however, have sufficient technical resources to display the complexity of the concept. They were developed on the basis of old technologies repeating the classic genre paradigm of "dialogue", "text quest", and a whole palette of arcades, that is, they once again confirmed the main thesis of Hal Foster that "design abets a near-perfect circuit of production and consumption, without much "running room" for anything else" (Foster, 2002, p.18). The problem of improper bets on genre,

\footnotetext{
${ }^{18}$ A little above Butler paraphrases Wittig, saying that "the language is in no way misogynist in its structures, but only in its applications". Butler's theory of gender represents an effective Subversion in pragmatics of language, carried out by taking the position of signification, which is the most economical solution to the problem of inertia of language praxis.
} 
- in other words, the problem of finding the utopian genre, notwithstanding the problem of divergence of the performative utterance and the appropriate conditions for its implementation, - and finally, the interpretation of the permanent soft-revolution as a total design, encourages us to change the optics and to apply it to the utopia of the medium, - namely, to try and find a different genre paradigm of discourse outside or beyond.

All this means carrying out the following mental operation.

We reduce the cyborg project of Haraway in direction to analytical syncretism and simultaneously present the subversive signifier stated by Butler as "multiple identification" as a medium. In other words, we direct our attention to strategies that are located in the area of controversial syntheses, which would open the way to multiple convergence and divergence; to begin with, it would represent the area of indetermination, but only as one aspect of sign, - namely, its mediality. We need this to make the medium genre.

This approach outlines two possible strategies, which can be described as

a) subversive integration into the medium, and

b) queerization of the medium, which will be the subject of further analysis.

\section{QUEERISATION OF THE MEDIUM}

Can we imagine queer as a medium? In order to answer this question, we should return to Butler's definition of multiple identifications. She writes: "multiple identifications can constitute a nonhierarchical configuration of shifting and overlapping identifications that call into question the primacy of any univocal gender attribution" (Butler, 1992, p. 66). The performativity of this gesture is explained by the following fact: Butler is trying to crack what she calls "paternal law" and what she also explains in terms of semiotics as "the founding Law of the Symbolic", which assigns primacy to the referent. In other words, she suggests questioning the "effectiveness" of established identities, opening the way for plurality and indeterminism. We know that the theory of multiple identifications formed the basis of the theory of the queer and was quickly adapted by a flexible neoliberal bureaucracy (Epstein, 1994). However, it did not find its own referent. 
Multiplicity has turned into multi-functionality, as can be seen in the examples of the campaign "You are also a queer!", claiming fatigue from the "patterns of unconventionality", and also in the cases of denying the title "queer" mentioned by Johnson in his article 'Quare' Studies, or (Almost) Everything I Know about Queer Studies I Learned from My Grandmother (2001). But even that is not the point. In her book Gender in trouble Butler, among other things, writes about rethinking the game of gender mutual definitions in terms of the "masquerade" relationship. A very important term if we are still keeping in mind the concept "total design", describing this evolution of the "society of performance". Explaining the term "Masquerade", Butler writes:

The term is significant because it suggests contradictory meanings: On the one hand, if the "being", the ontological specification of the Phallus, is masquerade, then it would appear to reduce all being to a form of appearing, the appearance of being, with the consequence that all gender ontology is reducible to the play of appearances. On the other hand, masquerade suggests that there is a "being" or ontological specification of femininity prior to the masquerade, a feminine desire or demand that is masked and capable of disclosure, that, indeed, might promise an eventual disruption and displacement of the phallogocentric signifying economy (Butler, 1992, p.46).

In other words, if earlier, in the classical phallocentric sign system, the phallus acted as a signifier, - that was its ontological status, - and the "being" of the phallus was signified, now what the "pre-ontological" nature of the Symbolic indicates is an ambivalence of signifying signs. A non-hierarchical symbolic system that avoids forced primary binarity liberates space for multiplicity. An unexpected criticism of this search for categorical flexibility (Kuznetsov, 2017) is Hal Foster's "diatribe", which, on a somewhat different, empirical level, returns to the Loos critique of the elimination of fundamental differences. Making a transparent allusion to the "signifier/signified" philosophy and taking this subversive approach ad extremum, Foster writes: "today you don't have to be filthy rich to be 
projected not only as designer but as designed - whether the product in question is your home or your business, your sagging face (designer surgery) or your lagging personality (designer drugs), your historical memory (designer museums) or your DNA future (designer children)" (Foster, 2002, p. 8).

Is this theoretical course of blurring oppositions a relapse of art of the end of the century? In any case, post-industrial design strategies fit multiplicity like nothing else and are ready to multiply options of acceptance by multiplying consumption facets.

The theoretical project of what we, combining now the terms of Simondon and Butler, could call an "indeterminate signifier" (Simondon, 1989), cannot find a referent that would not have been at the same time the consumption of options; in other words, would not consume the changing. But if we cannot find a referent, it is natural to turn to the only thing left, the structure of sign, the materiality of which we have forgotten. In his brilliant style Debray criticizes this omission of structuralism:

It is an edification in things got the wrong way round which reminds us that the dynamics of the message and the materiality of the base are either lost or found in tandem with one another. There have been some strange creatures christened in the Code's name. Given the status of objects are language without material inscription, speech without phonation, text without book, film without camera or filmstrip, painting without canvas (Debray, 1996, p. 72).

Is it not the "masquerade", the replacement of being by appearance and the reinterpretation of the ontological character of the Symbolic, the result of the same omission of the material side of the sign? After all, Debray's criticism here also concerns Saussure, who said that "language and writing are two distinct systems of signs; the second exists for the sole purpose of representing the first" (Saussure, 1966), and Barthes who completely deprived the symbol of mediality: "A pure social object that is indifferent to the matter or materiality of the signals composing it" (Barthes, 1964).

But now, deprived of materiality, the signs must obtain materiality again. My hypothesis is that ignoring this aspect of 
sign structure deprives theoretical constructions of the proper language, putting them in a form already approved by the market, involving them in the economy of desire, and in proliferation of false conceptions. Involving the appearance of a sign in a symbolic system should lead to a kind of practical theorization, where a change in discourse, its subversion, would mean a change in the appearance of the medium. All this call into question the very possibility of communication, but also opens the way to the analysis of "utopia" by means of the medium, and this, by itself, makes impossible the mentioned discrepancy between the sing and the referent.

I propose to consider the phenomenon of "author's" alphabet. According to Debray, one of the unfounded abstractions of the sign from the medium is abstraction from "the long history of cultural operations that determine and underline acts assumed to be simple (the forms and modes of reading, looking, writing, gathering and retrieving, etc.)" (Debray, 1996, p. 73). The sample of such an alphabet, developed by Moscow artist Anya Belousova, shows hieroglyphic layers. For clarity, I placed a photo of the alphabet next to a sample of Egyptian demotic writing (see photo below). This invented alphabet and, accordingly, the text written in it, belongs both to the type of hieroglyphic and phonetic writing at the same time. Each letter has characteristics of a plastic index sign, but, with the exception of variability, comparing to others it almost does not lend itself to the possible classification; it means, there is only an imitation of indexes; in fact, the plasticity of signs has a different nature. It reflects the recipient's physicality and is directly related to the artist's somatic, and, one might say, to mnemonic poetics (Balogun, 2018). Even this disposition reveals to us a picture of a surprisingly hermetic scene of auto-communication, an important characteristic of drafts (Gresillon, 1988). And, although a more detailed analysis of this kind of writing is beyond the scope of this article, it would be appropriate to indicate the features of such a specifically conditioned medium. First, this alphabet is somatic. It reflects the movement of the hand. Therefore, it is emotional, but in the sense of non-conventional indexes, -a cipher, a diary entry. 
According to one of authors of the textbook Mediareality (2017): "what we know about memory, and how we try to explain its action, is often determined either by metaphors taken from the field of media, or literally follows a particular media as a working model" (Media reality, 2017, p.121). This connection between the medium and mnemonics is fundamental and justifies the ontological character of the author's alphabet, referring us unintentionally to the history of the medium.

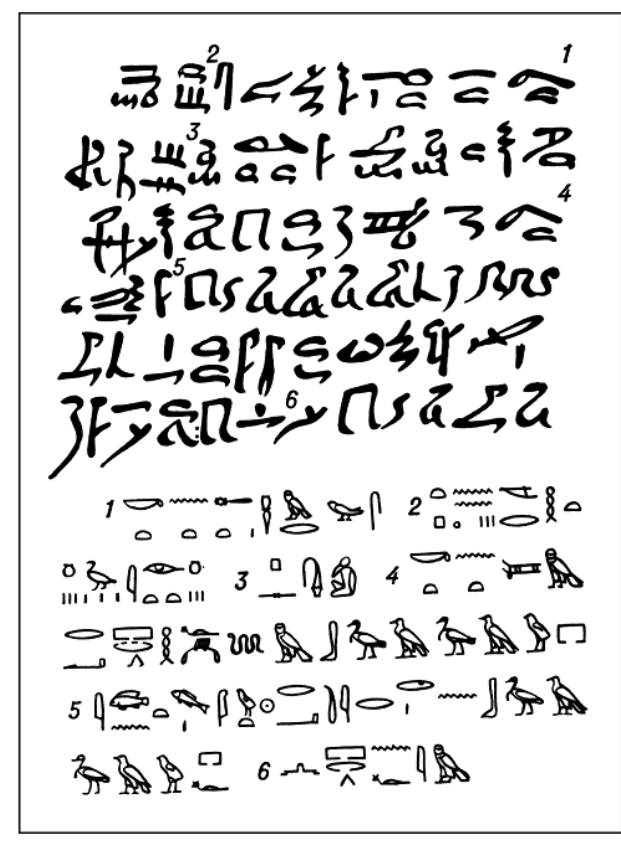

Fig. 1.

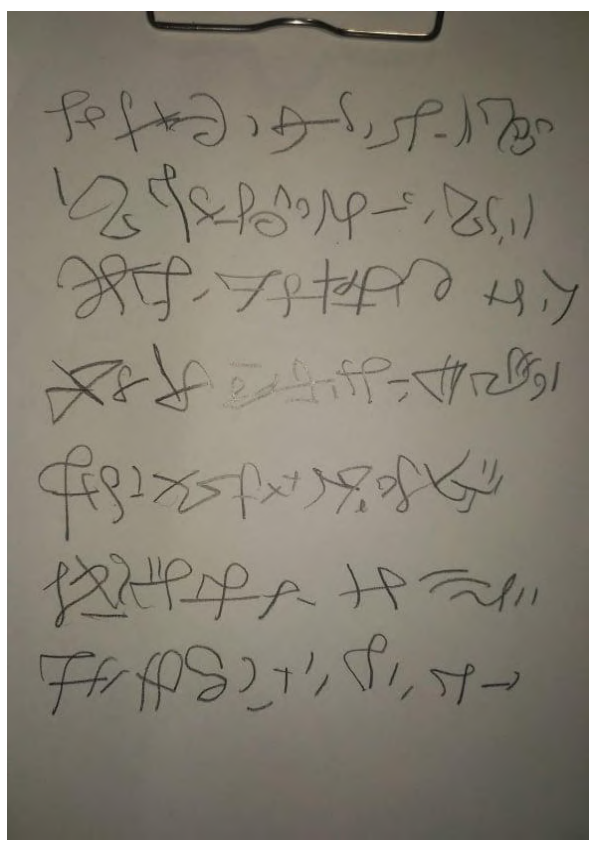

On the left, there is a sample of demotic writing. On the right, there is the alphabet created by Anya Belousova.

Elsewhere, the same author cites a study by Edward Casey, Remembering: a phenomenological study (Casey, 1987), determining the nature of signs that help to recall something:

A reminder sign may have an iconic resemblance to the object of the reminder or be associated with it by a stable cultural Convention, but, in fact, the well-known memory nodes are only a simple indication, a mark of a gap or, better to say, a cut in the continuity of experience, through which the forgotten past POPS up by itself without any meaningful 
connection with the reminding sign (Media reality, 2017, p. 125).

This coincides with the description of the method of reading by the artist herself. She says that it is not deciphered in any way, more precisely, it is deciphered using always different words. Such text is based rather on drawing principles. There is a rearrangement of forces: the verbal sign, which, according to Saussure, finds only its fixation in writing, becomes dependent on this fixation. The medium takes the lead. The artist insists that this is more of a drawing than a text, similar to sign language (Zucchi, 2012), consisting of the tension of lines, the shapes of lines, and the quality of lines. In other words, the medium-signifier acquires micro-semantics within its own body. As the character of the sign body changes, its interpretation becomes more or less detailed.

\section{CONCLUSION}

We find ourselves in a paradoxical situation of multiple identifications of sign causing its queerisation. The medium of the message does not have a stable form; it possesses instead a permanent meta-form, which relates directly to the recipient's somatic. We can interpret fluctuations in the form multiplied with more or less individual properties using a cluster of verbal signs.

One more point should be noted. We cannot ignore the aspect of the sign-medium's history. Debre lists among the later "achievements" of text-analysis such characteristics as homogeneity, stability, and conformity (Debray, 1996, p. 73). It is clear that the author's letter of Anya Belousova does not meet any criteria of mature writing, except that it is homogeneous. However, this is the homogeneity of the series of changes, in other words, this letter is constant about a group of features that change; it is stable in its instability. On the contrary, it is not conformal, and thus, due to the lack of social and market value, escapes the imperatives of consumption. This archaizing inclusion of the somatic in the process of transmitting a message through a given medium can be considered a subversive integration. 
References

Arns, I. (2005). Code as performative speech act. Artnodes, 0(4). https://doi.org/10.7238/a.v0i4.727

Atkin, A. (2013). Peirce's Theory of Signs. In The Stanford Encyclopedia of Philosophy, Edward N. Zalta (ed.). Retrieved from https://plato.stanford.edu/archives/sum2013/entries/peirce-semiot ics

Austin, J. (1962). How to do things with words. London, UK: Oxford at the Clarendon Press.

Balogun, L. (2018). Poetics of mnemonic strategy : the art of adaptation and the spirituality of being \& things in Tunde Kelani's Saworoide and The Narrow Path. Journal of African Films \& Diaspora Studies, 1, 53-74. doi: 10.31920/2516-2713/2018/v1n1a4.

Barthes, R. (1964). Elements of semiology. Communications 4, Paris, France: Seuil. (in French)

Butler, J. (1990). Gender Trouble: Feminism and the Subversion of identity. New York - London, NY, UK: Routledge, Chapman \& Hall, Inc.

Callis, S. (2009). Playing with Butler and Foucault: Bisexuality and Queer Theory. Journal of Bisexuality, 9:3-4, 213-233. doi: $10.1080 / 15299710903316513$

Casey, E. (1987). Remembering: phenomenological study. Bloomington, IN: Indiana University press.

Debord, G. (1992). La Société du Spectacle. Paris, France: Les Éditions Gallimard.

Debray, R. (1996). Media Manifestos. On the Technological Transmission of Cultural Forms, E. Rauth (trans.). London - New York, UK, NY: Verso.

Drescher, J. (2007). From bisexuality to intersexuality: Rethinking gender categories. Contemporary Psychoanalysis, 43(1), 204-228. doi: 10.1080/00107530.2007.10745905

Epstein, S. (1987). Gay politics, ethnic identity: The limits of social constructionism. Sociologist Review, 17(3/4), 9-54.

Epstein, S. (1994). A queer encounter: Sociology and the study of sexuality. Sociological Theory, 12(2), 188-202.

Foster, H. (2002). Design and Crime (And Other Diatribes). London - New York, UK, NY: Verso. 
Grésillon, A. (1988). Literary manuscripts: the text in all its forms. Practices: linguistics, literature, didactics, (57), 107-122. doi: 10.3406/prati.1988.1477 (in French)

Haraway, D. \& Wolfe, C. (2016). Manifestly Haraway. Minneapolis, MN: University of Minnesota Press.

Jameson, F. (1990). Cognitive Mapping. In C. Nelson \& L. Grossberg (Eds.), Marxism and the Interpretation of Culture (pp. 347-60). Champaign, IL: University of Illinois Press.

Johnson, P. (2001). "Quare" Studies, or (Almost) Everything I Know about Queer Studies I Learned from My Grandmother. Text and Performance Quarterly. 21, 1-25. doi 10.1080/10462930128119.

Kuznetsov, V. (2017). Conceptual Plasticity as a Postclassical Way to Conceptualize the Elusive Unity of the World. RUDN Journal of Philosophy. 21(2), 213-221. doi 10.22363/2313-2302-2017-21-2-213-221 (in Russian)

Saussure, F. (1966). Course in General Linguistics, W. Baskin (trans.). New York, NY: McGraw-Hill.

Simondon, G. (1989). The mode of existence of technical objects, J. Hart (pref.), Y. Deforge (postf.). Alençon, France: Aubier. (in French)

Todorov, T. (1975) The Fantastic a Structural approach. Ithaca, NY: Cornell University press

Zucchi, A. (2012). Formal Semantics of Sign Languages. Language and Linguistics Compass, 6. Doi 10.1002/lnc3.348.

Список литературы

Arns, I. (2005). Code as performative speech act. Artnodes, 0(4). https://doi.org/10.7238/a.v0i4.727

Atkin, A. (2013). Peirce's Theory of Signs. In The Stanford Encyclopedia of Philosophy, Edward N. Zalta (ed.). Retrieved from https://plato.stanford.edu/archives/sum2013/entries/peirce-semiot $\underline{\text { ics }}$

Austin, J. (1962). How to do things with words. London, UK: Oxford at the Clarendon Press.

Balogun, L. (2018). Poetics of mnemonic strategy : the art of adaptation and the spirituality of being \& things in Tunde Kelani's Saworoide and The Narrow Path. Journal of African Films \& Diaspora Studies, 1, 53-74. doi: 10.31920/2516-2713/2018/v1n1a4.

Barthes, R. (1964). Elements of semiology. Communications 4, Paris, France: Seuil. (in French) 
Butler, J. (1990). Gender Trouble: Feminism and the Subversion of identity. New York - London, NY, UK: Routledge, Chapman \& Hall, Inc.

Callis, S. (2009). Playing with Butler and Foucault: Bisexuality and Queer Theory. Journal of Bisexuality, 9:3-4, 213-233. doi: 10.1080/15299710903316513

Casey, E. (1987). Remembering: phenomenological study. Bloomington, IN: Indiana University press.

Debord, G. (1992). La Société du Spectacle. Paris, France: Les Éditions Gallimard.

Debray, R. (1996). Media Manifestos. On the Technological Transmission of Cultural Forms, E. Rauth (trans.). London - New York, UK, NY: Verso.

Drescher, J. (2007). From bisexuality to intersexuality: Rethinking gender categories. Contemporary Psychoanalysis, 43(1), 204-228. doi: 10.1080/00107530.2007.10745905

Epstein, S. (1987). Gay politics, ethnic identity: The limits of social constructionism. Sociologist Review, 17(3/4), 9-54.

Epstein, S. (1994). A queer encounter: Sociology and the study of sexuality. Sociological Theory, 12(2), 188-202.

Foster, H. (2002). Design and Crime (And Other Diatribes). London - New York, UK, NY: Verso.

Grésillon, A. (1988). Literary manuscripts: the text in all its forms. Practices: linguistics, literature, didactics, (57), 107-122. doi: 10.3406/prati.1988.1477 (in French)

Haraway, D. \& Wolfe, C. (2016). Manifestly Haraway. Minneapolis, MN: University of Minnesota Press.

Jameson, F. (1990). Cognitive Mapping. In C. Nelson \& L. Grossberg (Eds.), Marxism and the Interpretation of Culture (pp. 347-60). Champaign, IL: University of Illinois Press.

Johnson, P. (2001). "Quare" Studies, or (Almost) Everything I Know about Queer Studies I Learned from My Grandmother. Text and Performance Quarterly. 21, 1-25. doi 10.1080/10462930128119.

Saussure, F. (1966). Course in General Linguistics, W. Baskin (trans.). New York, NY: McGraw-Hill.

Simondon, G. (1989). The mode of existence of technical objects, J. Hart (pref.), Y. Deforge (postf.). Alençon, France: Aubier. (in French)

Todorov, T. (1975) The Fantastic a Structural approach. Ithaca, NY: Cornell University press 
Zucchi, A. (2012). Formal Semantics of Sign Languages. Language and Linguistics Compass, 6. Doi 10.1002/lnc3.348.

Кузнецов, В. (2017). Концептуальная гибкость как способ постижения ускользающего единства мира. Вестник Российского университета дружбы народов. Серия: Философия. 21(2), 213-221. doi 10.22363/2313-2302-2017-21-2-213-221 (in Russian) 